\title{
URBAN SPACE EXPERIENCE AND PERCEPTIONS OF SYRIAN REFUGEE CHILDREN
}

DOI: http://dx.doi.org/10.18509/GBP.2017.28

UDC: 314.151.3-054.73:316.733

\author{
Muazzez Harunoğulları ${ }^{1}$ \\ Yadigar Polat ${ }^{2}$ \\ ${ }^{1}$ Kilis 7 Aralık University, Faculty of Arts and Sciences, \\ Department of Geography, Kilis, Turkey. \\ ${ }^{2}$ Kilis 7 Aralık University, Vocational Higher School of Health Services, \\ Department of Medical Services and Techniques, Kilis, Turkey.
}

\begin{abstract}
As a phenomenon witnessed throughout history, migration can occur voluntarily due to economic and social reasons but it can also happen by necessity due to wars which are considered human disasters. As a result of civil wars, people are forced to leave the geography, land, neighborhood they live in, relatives and neighbors they have, and their pasts and experiences they have. Most of the people who migrate are women and children. Among them, children without parents constitute a large majority.

The purpose of this study is to examine the urban spaces the Syrian children live in and their experiences in these spaces. In this study, Syrian children's urban space perceptions and use, sense of belonging, life challenges, employment status, problems they face and future expectations were discussed. In-depth interviews were conducted and observation method was employed with the Syrian children who were selected using simple random sampling.

Syrian civil war has turned millions of Syrians into refugees. 50\% of the refugees are children. Holding on to life is very difficult for refugee children who witnessed the horrors of war. As a result of the study, it was found that majority of the refugee children living in the city of Kilis do not go to school, and these poor children have to work in the streets or in odd jobs to help their family economically.

Having experienced the war and its suffering first hand, Syrian children face risks like psychological disorders, violence, child marriages, working under difficult conditions and being forced to be members of armed groups. These children who had to leave the geography they lived are trying to adopt and get used to the new geography they came. Trying to adopt to a new life in a new space, the fears and anxieties these children live are extremely deep. Preserving their identities in a different culture or creating new identities shape children's cognitive worlds and their future expectations.
\end{abstract}

Keywords: Syrian refugees, migration, child refugees, urban space, asylum seeker.

\section{INTRODUCTION}

From past to present, millions of people have migrated due to social and political reasons, security issues, natural disasters and to have better living conditions. Today, more than six million [1] Syrians had to leave their country. This number has surpassed the refugee numbers from the Rwandan genocide, the largest refugee crisis since World War II [2]. 
Guardian and protector of the oppressed nations throughout history, Turkey is a country embracing different identities and culture. For people running away from the totalitarian regimes of their country and the civil wars, Turkey is a safe haven for the citizens of neighboring countries.

With the civil war in Syria, millions of Syrian refugees have come to our country since 2011. As a result of the civil war that started in 2011, as of April 2016, while the Syrian refugee numbers in our country was 2.749 .140 , total number of Syrian children in our country was 1.490 .033 (54\% of the Syrian population that came to our country) [2]. Hosting nearly 3.6 million (3.551.078) refugees, Turkey today is the country with the world's largest refugee population. Since the beginning of the Syrian crisis, Turkey has spent 25 million dollars on refugees [3]. Placing more than 250.000 refugees in 26 camps, Turkey has been meeting their health, educational, nutritional, social and other needs. $90 \%$ of the Syrian refugees outside camps live in urban and rural areas under very difficult conditions with the help of the government, local administrations and host communities. By September 2016, the total humanitarian aid provided by the EU to Turkey was only 538 million $€$ [4]. This amount is tremendously low considering the number of Syrian refugees living in Turkey. One of the cities feeling the population pressure of Syrian refugees on social space the most is Kilis. While the urban population of the city of Kilis was 93.222 [5] in 2016, the number of Syrians living in the city in 2016 was 117.000 [6]. Children and adolescents constitute more than half of the Syrian population in the city. It is not expected from the people who migrate to safer countries as a result of drastic condition to easily adapt to the new geographical space. Facing many difficulties due to everyday life changes in their new society, refugee children are terribly struggling to adapt. Having to deal with many difficulties like trauma caused by war, dying family members due to air attacks, poverty, hunger and lack of shelter and nutrition, refugee children are developing methods to solve these problems themselves. The meanings refugee children attribute to geographical spaces are changing and transforming.

Geographical spaces are important in rebuilding people's identities. The cultural patterns of the geography they once live in are reshaped in the geography they come to. Syrian refugees have started a process of creating a new space in the city of Kilis. They started to live with their own people in the neighborhoods they moved into and built their own businesses. The space at first is their home but the space is also the street they live in, the neighborhood, the streets of the city, the bazaar, the school, the workplace or the other parts of the city. All these spaces create new schemata in children's minds and prepare them for the future. Shelter is the most important problem arising for children in this new natural and social environment. Those whose economic situation is slightly better reside in appropriate houses whereas those whose economic situation is not good and those who do not have a job and need others' help live in uninhabitable dwellings on the outskirts of the city. The houses refugee children live in have an important place in their cognitive, psychological and biological developments. Living unhealthy lives in uninhabitable houses, many of these refugee children are struggling against living conditions with their families or alone.

Instead of going to school in the city they live in, children between the ages 6 and 18 are working in the city to contribute to the family economy. Children who feel safer in the neighborhoods they live in work in different jobs in the streets of the city to survive. Children who sell chocolate and wafer or children who collect garbage wander all the Kilis streets. Many of the working children have to work since their parents want them to work. Poor refugee children stay away from schooling and build their futures in the 
streets. Adaptation to the new space and survival by learning the space is at stake for majority of the children working in the streets. Many of the run-down buildings they live in are unhealthy.

\section{RESERCH AREA}

During the ancient times, Kilis had been a strategically important settlement because of its location between Mesopotamia and Anatolia and because of being on the Silk Road route. The city is to the south of Turkey, on the Syrian border, and surrounded by Gaziantep from the north-northeast-east and west (Figure 1). With 680 meters above the sea level, the city was founded on a tectonic plain. From north to south, towards the Syrian border, the elevation decreases. The Mediterranean Climate is seen in the city, and raising pistachios and olives and viticulture are the main agricultural activities. Hosted many civilizations, Kilis has a rich historical texture belonging to different cultures.

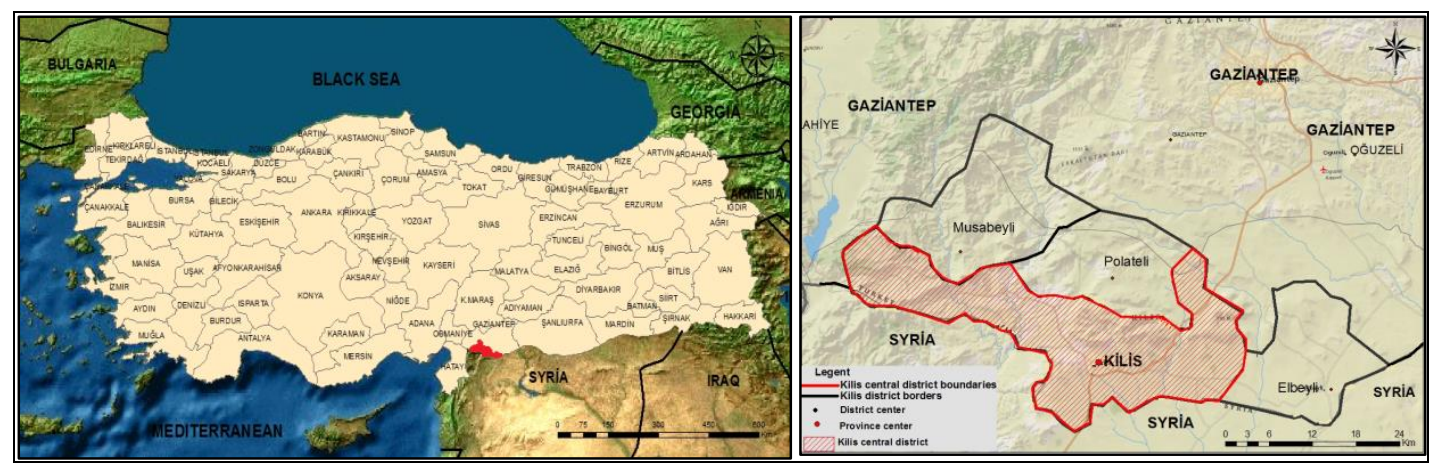

Figure 1. Location of Kilis City.

\section{PURPOSE AND METHOD}

Migration studies, one of the subjects of human geography, in recent years require the transnational spaces, transnational communities and displaced children be discussed under the migration phenomenon. In this context, the purpose of the study is to examine the urban spaces Syrian refugee children in Kilis live in and their experiences and perceptions about these spaces. Syrian refugee children's urban space perceptions, their use of these spaces, their sense of belonging, life problems, employment situations, problems they encounter and their expectations for future are discussed in the study.

The study employed in-depth interviews and participant observations. In this context, indepth interviews were conducted with 28 Syrian children between the ages of six and fourteen who were randomly selected. The data was obtained through semi-structured interview. For the children to feel comfortable, the interviews were conducted in a conversation mode. Interview method is an effective method used to put forth people's experiences. Furthermore, observations employed at different times in the city of Kilis in 2016-2017 were added to the study. The study was conducted through children's words. It is not easy to enter children's worlds and to convey their feelings, experiences and aspirations.

\section{FINDINGS}

\section{Spatial perception and belonging}

People are primarily temporal, and they find meaning in the temporal feature of their existence. People actually live time in spaces in terms of quality. The importance of spatial relation depends on the special feature of the particular objects [7]. The concept 
of space has a psychological, social and cultural dimension comprised of meaning, symbol and feelings. Space expresses the interlock between the physical dimension, the personal dimension like meaning and feelings and social dimension made up of structural relations [8]. Space is the foundation of economic and social relations. It connects what is cognitive with cultural and what is social with historical. Geographic space comes to life with the movements and actions of its residents [9].

Spatial/physical environment conditions the children live in affect their personalities, behaviors and perceptions. In addition, these conditions have an important place in children's socialization and development as society's members in social spaces. Areas like houses the children live in, neighborhoods, playgrounds and malls are the urban spaces that have an important place in children's personality development and perspective on life. The spaces they live do not only have a great impact on children's mental world but also on their biological development.

Individuals feel the spaces they live in beyond a physical perception. They get attached to these spaces, and a sense of belonging develops in these spaces. Space and identity exist together [10]. There is trauma in the psyche of the children who were exposed to violence and lived the fear of death. Because of the traumas they had faced, the stress and anxiety levels of children increase, and they experience sleep disturbances.

"When we were shopping during the war, bombs dropped from the planes. A lot of people died and got hurt. Houses were destroyed, our relatives and my friends died, I was very scared that I was going to die. I still see those moments in my dreams at night." (Emeni, 10 years old)

Their experiences during and after the migration can be quite sad. The Syrian refugee children interviews stated that they had to be extremely cautious not to be seen by the regime soldiers and the terrorist groups in the region and that they made great efforts to avoid getting captured. The refugees who set off at night reached the Turkish border on foot or by car after sending a child ahead and after making sure the region was safe.

"I was very scared while coming to Kilis. While we were migrating, the Russian planes dropped bombs on us. The bombs fell very close to us. We barely escaped death. I was so scared the bombs would fall on top of us. " (Ayşe, 7 years old)

Syrian children who got separated from their parents constitute the most fragile and weak part of the migration process.

"My mom and dad stayed in Syria. Me and my brothers are living with my grandmother here. I collect plastic from the trash. Nobody is working in the family. My grandmother is very old. My biggest aspiration is to go to my mom in Syria." (Necla, 12 years old) Children living in the migrated country enter a process of identity development by getting affected rom the environmental conditions. Adjustment to the different culture they have entered is a long process and an important concern. Far away from their own country geographically, these refugee children maintain their lives with low income. The sociocultural adjustment process is gradual, and the host society and refugees integrate in different areas [11]. Looking to the space they live in from their own window, refugee children's perceptions and feelings will differ from their parents' perceptions and feelings because children's thoughts they developed about the space in their own inner world are different than adults' thoughts.

"We can go out in the neighborhood comfortably. But the two children of our neighbor take me and my brother on. They bother us. I don't like this neighborhood at all." (Ali, 7 years old) 
Children socialize by interacting in the environment they live in. Children who are exposed to negative experiences in the spaces they live in may take dangerous and wrong roads. Leading the future of their society, children should be provided opportunities for them to complete their physical and mental development and to be an adult adjusted to the society [12]. $10 \%$ of the interviews Syrian refugee children stated that they experience adjustment problems to the local population. The others stated that they get along with the locals and that they have no problems. Not knowing the language lies at the core of their adjustment problems. Children who can speak Turkish experience a healthier adjustment to the space. The positive or negative feelings about a space reveal where children position themselves. Children's sense of belonging towards the space they live in is about feeling safe, peaceful and happy there. The friendships they create affect refugee children's ties and feelings they have for Kilis. They expressed that they do not feel like the "other" if they feel happy and peaceful where they live in and that they feel alien and isolated if they are not happy and peaceful.

"I have friends at school and in the neighborhood. I get happy when I go to school. I get along with my friends. I like Kilis when I get along with my friends. I want to return to Syria when I don't get along with them." (Mustafa 10 years old)

The process of network-forming areas in the space being meaningful is possible when these areas intersect with the daily experiences of people in that space. The most meaningful of these intersection areas for the individual is home. Home is an important concept for existence, maintenance and for finding identity [13]. The spaces refugees settle often trigger social exclusion. Settling in spaces appropriate to their budget, Syrian refugees mostly found accommodation in poor neighborhoods. The ones who have low incomes and who live in economic hardship face spatial exclusion [14]. The results of a study done on the city revealed that most of the Syrian refugee children live in unhealthy, damp and run-down places with small window that were turned from a garage. Living in extremely unhealthy conditions, these children have biological and psychological problems due to inadequate nutrition and heating.

The problems during the accommodation and employment process in the new country can lead to being excluded from cultural, economic and political processes [15]. The employment of children and the abuse of child labor are among the major social problems all around the world. Making up a different section of child labor, children working on the streets have to meet their families' economic needs by working. During the day, these streets constitute the most important spaces where daily activities take place [16]. Their need to work because of economic hardships make Syrian refugee children vulnerable to exploitation. In terms of migration and problems brought about by migration, children are an invisible mass. Life is difficult for refugee children who are faced with low income, parent unemployment, working, unhealthy development, inadequate nutrition, health problems, social exclusion, being seen as the other and not continuing their education. Children who feel safer in the neighborhoods they live in work at different jobs on the streets to survive. Some children try to contribute to the family income by selling paper tissues, chocolate or crackers; some by collecting trash or plastic waste early in the mornings or late at nights; some beg. These children, both boys and girls, are between five and 14 years old, and continue to live their lives like this. Most of the Syrian refugee children who cannot have education learn informally on the streets. Some of the children learned Turkish on the streets where they collect trash or sell tissues or chocolate.

As a result of the conflict in Syria, especially young girls have to cope with many problems like interruption in education, violence, early marriage and sexual abuse. While 
more than 53\% of the Syrians in Turkey are children and adolescents under the age of 18, more than $75 \%$ of them are children and women in need of special protection [17]. Tens of thousands of Syrian children not being able to continue their education due to war will have profound consequences for societies over the next decades. The skills Syrian refugee children need to secure their futures can be provided with education. Refugee children who are not given opportunities to continue their education will not only cause social instability in the future but also the future generations will lose hope, and their poverty levels will increase. Furthermore, their chance to improve their living conditions will be taken from their hands. The rate of child labor among Syrian children are quite high [18].

"I voluntarily support my family financially. I buy milk to my one-year old brother with the money I earn by selling crackers and chocolate on the street." (Ahmet, 10 years old)

\section{CONCLUSION AND DISCUSSION}

Syrian refugee children who cannot go to school have an informal education in the streets. Also, these refugee children are mistreated by their refugee peers who claim the space or older people. Protecting the refugee children is the responsibility of both governmental agencies and non-governmental organizations. Donations to the poor families, providing job opportunities to the parents and opening various vocational courses for women are among the steps that can be taken.

Schooling and vocational courses should be provided for children without parents who need to work in order to guarantee their future. Some of the interviewed children stated that they do not want to continue their education. The most important factor behind this is that they are behind their peers age wise since they had to stop going to school for a long time. In addition to providing courses where they will learn a skill, an environment where they can continue their basic schooling should be provided.

It was observed that many of the interviewed children live in unhealthy buildings, and their basic needs like food and heat are not met. Living in tremendously unhealthy spaces, these children are in biological and psychological distress since they do not have adequate food and a warm house. Necessary support should be given to Syrian refugees by local administrations after identifying the neighborhoods and places they live in. Shelter, food and heat assistance to refugees will reduce the number of refugee children working in the streets and will help them become biologically and psychologically healthier individuals. Syrian families should be persuaded for the continuation of their children's education by contacting them. For people who want to help the refugees, aid centers should be set up to meet refugees' needs.

\section{REFERENCES}

[1] UNHCR, Syria Regional Refugee Response-Regional Overview, http://data.unhcr.org/syrianrefugees/regional.php, April, 2016.

[2] Ulbrick, T. R2P and the Case for the Syrian Buffer Zone, Foreign Affairs, November $12,2014$.

[3] Ahaber, Bakan Soylu, Türkiye'deki mülteci sayısını açıkladı. 15.02.2017. www.ahaber.com.tr/gundem/2017/.../bakan-soylu-turkiyedeki-multeci-sayisini-acikladı

[4] European Commission, Humanitarian Aid and Civil Protection, Turkey: Refugee crisis, ECHO Factsheet - Turkey - September 2016: 1-2.

[5] TÜİK, Türkiye İstatistik Kurumu Adrese Dayalı Nüfus Kayıt Sistemi, 2016. 
[6] T24, Suriyeli sayısının yerli nüfusu geçtiği Kilis'te kiralar patladı,

t24.com.tr/haber/suriyeli-sayisinin-yerli-nufusu-gectigi-kiliste-kiralar-patladi， 328204 , February 15, 2016.

[7] Urry, J. Mekanları tüketmek, çeviren Rahmi G. Öğdül, Ayrıntı yayınları, İstanbul, 1995.

[8] Uysal, A. Emotional geographies of Turkish children in transnational spaces in London, Göç Dergisi, 3 (1), pp. 99-119. 2016.

[9] Lefebvre, H. Mekanın Üretimi, Çeviri Işık Ergüden, Sel Yayıncılık, İstanbul. 2014.

[10] Görengeli, M. Karakuş, P. Göç Araştırmalarında Mekan Boyutu: Kültürel ve Mekansal Bütünleşme, Türk Psikoloji Yazıları, 17 (34), pp. 101-115, 2014.

[11] Fazel, M. V Reed, R. Panter C. -Brick, Stein. A. Mental health of displaced and refugee children resettled in high-income countries: risk and protective factors, Review Vol 379 266-282, DOI:10.1016/S0140- 6736 (11) 60051-2, www.thelancet.com January 21, 2012.

[12] Kaplan, B. Çalışkan, Z. Evgin, D. Caner, N. A Universal Problem: Juvenile pushed to crime and victim of crime, Gümüşhane University Journal of Health Sciences, 5 (2), pp. 10-15. 2016.

[13] Aslanoğlu, Rana A. Kent Kimlik ve Küreselleşme, Ezgi kitapevi, Bursa. 1998.

[14] Deniz, A.Ç. Ekinci, Y. Hülür, A.B. Suriyeli Sı ğınmacıların Karşılaştığı Sosyal

Dışlanma Mekanizmaları, Sosyal Bilimler Araştırma Dergisi, Year 14, (27), pp.17 - 40. 2016.

[15] Tümtaş, M. S. and Ergun, C. Göç ve Yoksulluk Kıskacında Yıkılan Bir Kent: Van, Journal of Academic Approaches, Volume: 5 Issue:2, pp. 1-23. 2014.

[16] Bilgin, R. A sociologic study on the children working on the streets in Diyarbakır, Electronic Journal of Social Sciences, 8 (27), pp. 232-244. 2009.

[17] Çevik, S.A. The effects of migration from Syria to Turkey, Gümüşhane University Journal of Health Sciences, 5 (2), pp. 80-83. 2016.

[18] Watkins K. and Zyck. S. A. Living on hope, hoping for education The failed response to the Syrian refugee crisis, Report, 2014. 